Gut, 1980, 21, 941-947

\title{
Immunoglobulin containing cells in inflammatory bowel disease of the colon: a morphometric and immunohistochemical study
}

\author{
P C M ROSEKRANS, * C J L M MEIJER, A M VAN DER WAL, \\ C J CORNELISSE, AND J LINDEMAN
}

From the Department of Gastroenterology and Pathology, University Medical Centre, Leiden, the Netherlands

SUMMARY Immunoglobulin containing cells in rectal and sigmoid colonic mucosa in endoscopically obtained biopsies from 10 patients with ulcerative colitis and 10 patients with Crohn's disease were studied, using an indirect immunoperoxidase technique. These findings were compared with the immunoglobulin containing cell number in colonic biopsies from 10 control patients with no evidence of colitis. In biopsies from the 20 patients with inflammatory bowel disease a marked increase in area of the lamina propria per millimetre mucosa length was found. In ulcerative colitis a marked increase in number of IgG containing cells was observed. In Crohn's disease the increase in IgG containing cell number is dependent on the degree of activity of inflammation. In quiescent or active Crohn's disease of the colon we found a significant increase of the IgM containing cells. The number of IgM containing cells per millimetre mucosa length will differentiate the pathology of Crohn's disease from ulcerative colitis.

Ulcerative colitis and Crohn's disease are chronic inflammatory conditions of the gastrointestinal tract of unknown aetiology and pathogenesis. The large numbers of lymphocytes and plasma cells in the infiltrate of the large bowel mucosa in patients with inflammatory bowel disease is consistent with an immunological mechanism in these diseases.

The inflammatory infiltrate, especially the immunoglobulin containing cells, in the gut has been the subject of a number of quantitative studies. ${ }^{1-8}$ All these authors used an immunofluorescence technique and their quantitative methods varied. In most studies an increase of IgA and IgG containing cells was found in inflammatory bowel disease. Skinner and Whitehead ${ }^{4}$ and Baklien and Brandtzaeg $^{6}$ showed that in active ulcerative colitis and Crohn's disease the increase was greatest for IgG and IgM containing cells. O'Donoghue and $\mathrm{Kumar}^{8}$ found in both diseases a marked increase in IgE containing cells in rectal mucosa. Only a few authors have looked at the inflammatory infiltrate with the immunoperoxidase technique ${ }^{79}$ although the immunoperoxidase technique on paraplast

*Address for correspondence: Dr P C M Rosekrans, St Elisabeth Ziekenhuis, PO box 220, 2350 AE Leiderdorp, The Netherlands.

Received for publication 18 August 1980 embedded tissue-sections has the advantage of permanence of the sections and is more suitable for morphometric study than immunofluorescence on frozen sections. Meuwissen et al. ${ }^{7}$ have found in inflammatory bowel disease a low number of IgG containing cells, while, on the contrary, Otto and Gebbers $^{9}$ have found a marked increase of IgG containing cells in ulcerative colitis.

The main purpose of our present work was to study the number of immunoglobulin containing cells in colonic mucosa in endoscopically obtained biopsies from patients with ulcerative colitis and Crohn's disease. Using an indirect immunoperoxidase technique, we determined the number of $\operatorname{IgA}, \mathrm{IgG}, \operatorname{IgM}, \operatorname{IgD}$, and IgE containing cells in the colonic lamina propria. The pattern of immunoglobulin containing cells in the two groups of patients with inflammatory bowel disease differs considerably and can be of diagnostic help

\section{Methods}

PATIENTS

Three groups of patients were studied.

Ulcerative colitis

There were 10 patients with ulcerative colitis 
(average age 37 years; range $27-63$ years) in this group. The diagnosis was based on clinical, radiological, endoscopical and histological findings. ${ }^{10}$ All patients in this group had a severe inflamed mucosa in the sigmoid colon and rectum. Seven patients were treated with oral sulphasalazine and in three of these patients it was combined with topical corticosteroid treatment.

\section{Crohn's disease}

In this group were 10 patients with Crohn's disease of the colon (average age 34 years; range 21-49 years). The history, radiological and endoscopic findings were typical for a colonic localisation of Crohn's disease. The diagnosis was based on histopathological criteria described by Whitehead ${ }^{11}$ and Morson $^{10}$ for mucosal biopsies and summarised by Meijer et al. ${ }^{12}$ Seven patients were treated with oral sulphasalazine and three of these patients used a low dose of corticosteroids.

Because of the segmental involvement of the colon in Crohn's disease in a number of cases there were only minor signs of inflammation in the distal part of the colon. In seven patients we compared the biopsy findings from the rectum and sigmoid with areas of more active inflammation in the transverse or descending colon.

\section{Control patients}

There were 10 control patients with no sign of colitis in whom a colonoscopy was performed because of a single polyp or the irritable bowel syndrome (average age 35 years; range 19-64 years).

\section{PROCEDURES}

In every patient at least two biopsy specimens were obtained during endoscopic examination, one biopsy from the sigmoid and one from the rectum. The biopsy specimens were fixed in a sublimateformaldehyde mixture. ${ }^{13}$ After fixation for three hours the tissue samples were embedded in paraplast. Tissue sections were cut $4 \mu \mathrm{m}$ thick, perpendicular to the luminal surface and mounted on glass slides. Sections were stained with haematoxylin and eosin (HE) and periodic acid Schiff (PAS), and specifically for IgA, IgG, IgM, IgD, and IgE heavy chains, using an indirect immunoperoxidase technique ${ }^{13}$ Appropriate controls were done according to Sternberger. ${ }^{14}$ Rabbit antisera against IgA, IgM, and IgG heavy chains were purchased from Dakopatts (Denmark). The rabbit antisera against IgD and IgE heavy chains were purchased from the Central Laboratory of the Netherlands Red Cross Blood Transfusion Service, Amsterdam. The specificity of these antisera was confirmed by immunoelectrophoresis and cytoplasmic immunofluorescence and immunoperoxidase staining on mono- clonal bone marrow preparations. ${ }^{15}$ The rabbit antiIgE antiserum showed no positive reaction with bone-marrow preparations monoclonal for $\operatorname{IgA}$, IgM, IgG, or IgD heavy chains and their respective $\chi$ or $\lambda$ light chains. Horse radish peroxidase labelled goat anti-rabbit IgG was obtained from Miles (Yedah, Israel).

The IgA, IgG, IgM, and IgE stained sections were used for morphometric study. Images of the immunoperoxidase stained sections were projected with a standard magnification of $\times 200$ on graph paper and drawings were made. Morphometric analysis of the drawn figures were made on a graphic tablet (Tektronix) interfaced to a small laboratory computer (PDP 11/10; Digital Equipment Corporation, Maynard, Mass. USA). ${ }^{16}$

In every immunoperoxidase stained section the lamina propria area was measured per $\mathrm{mm}$ mucosa length. Thus we measured the number of immunoglobulin containing cells in a 'mucosal tissue unit' defined as a $4 \mu \mathrm{m}$ thick and $1 \mathrm{~mm}$ wide block of tissue, including the mucosa at full height from the muscularis mucosae to the surface epithelium. This 'mucosal tissue area' is comparable with that of Brandtzaeg. ${ }^{1 \bar{i}}$

Because of the shrinkage of the biopsy especially

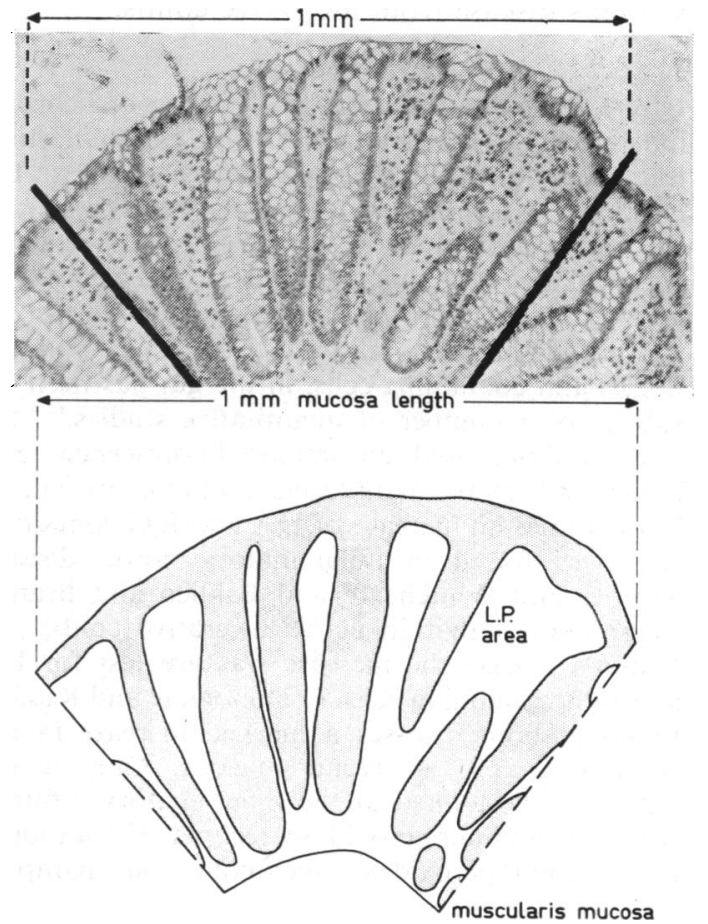

Fig. 1 Scheme for morphometry of measuring lamina propria area per mm mucosal length. For explanation see text. 


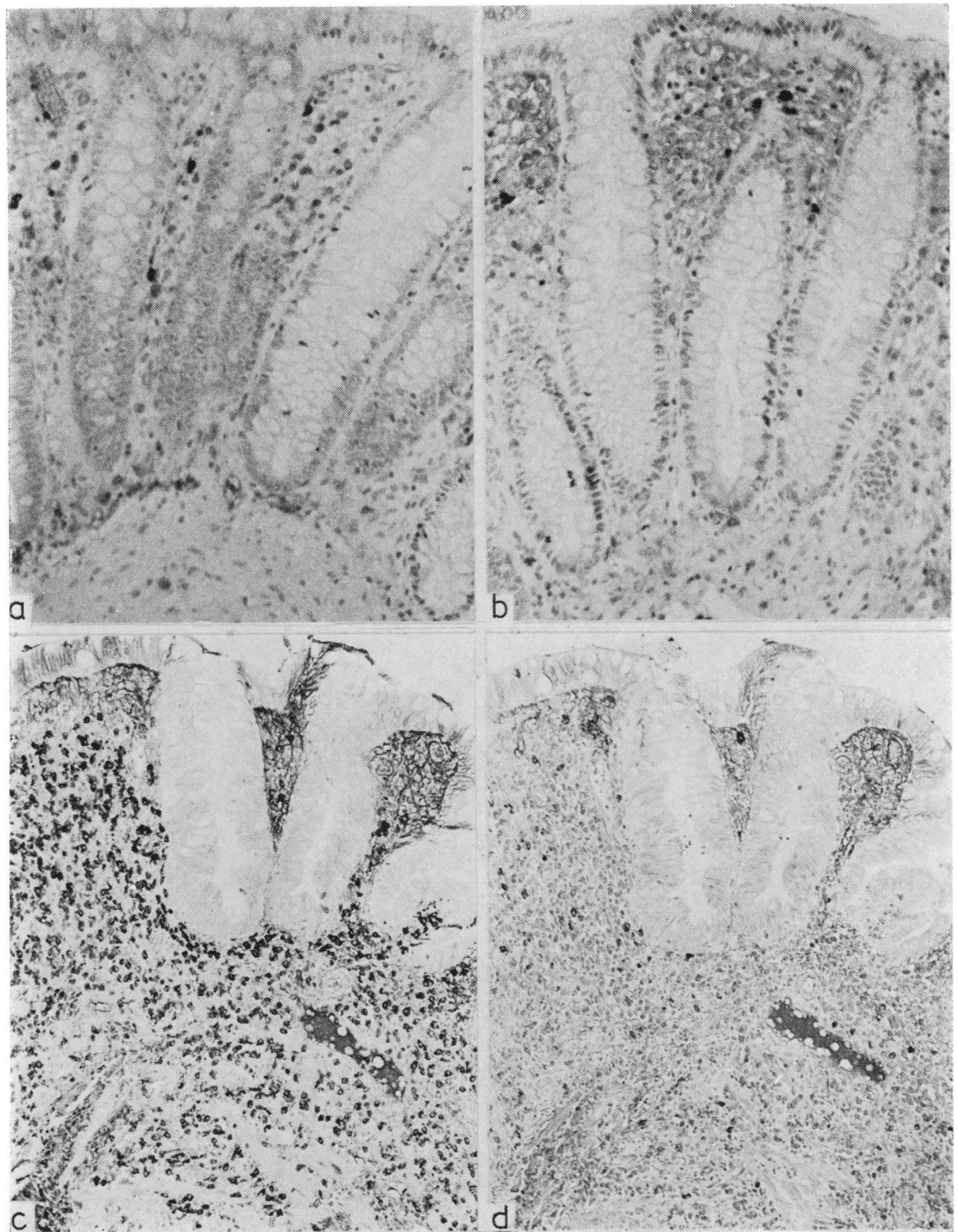

Fig. 2 Immunoperoxidase staining of mucosal biopsy specimens of the colon. (a) IgG containing cells in normal rectum mucosa $(\times 100)$. (b) IgM containing cells in normal rectum mucosa $(\times 100)$. (c) IgG containing cells in rectum mucosa of an ulcerative colitis patient $(\times 64)$. (d) IgM containing cells in rectum mucosa of an ulcerative colitis patient $(\times 64)$.

on the basal side, from contraction of the muscularis mucosae, a correction of the lamina propria area per mm surface mucosa length was necessary: the lamina propria area was limited by two lines, parallel to the crypts perpendicular to the muscu- laris mucosae (Fig. 1). The immunoglobulin containing cell number was counted in the known lamina propria area in three consecutive sections and expressed per $\mathrm{mm}^{2}$ lamina propria area and per $\mathrm{mm}$ mucosa length. 


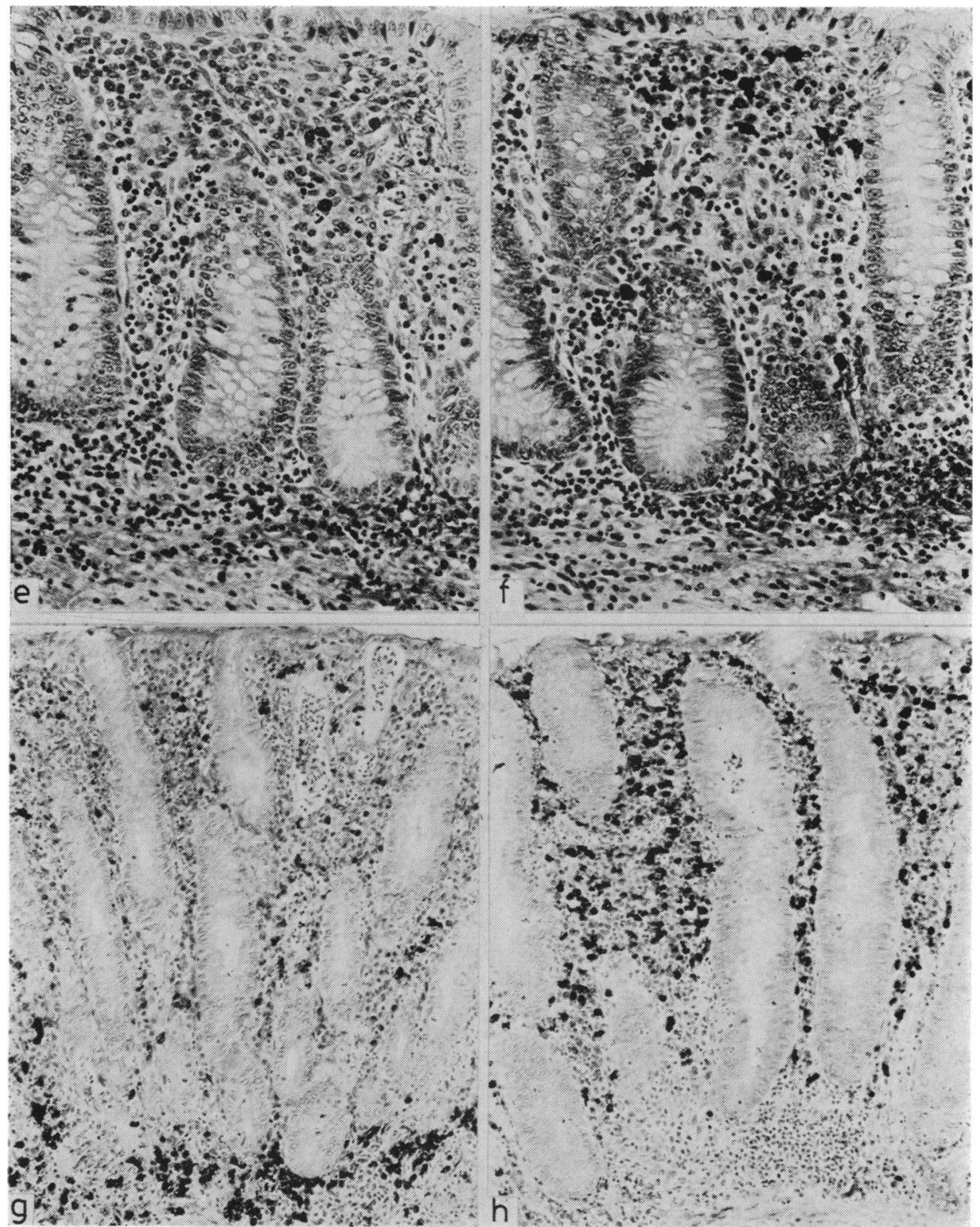

(e) IgG containing cells in a quiescent part of the colon in Crohn's disease $(\times 100)$. (f) IgM containing cells in a quiescent part of the colon in Crohn's disease $(\times 100) .(g)$ IgG containing cells in an actively inflamed part of the colon in Crohn's disease $(\times 80)$. (h) IgM containing cells in an actively inflamed part of the colon in Crohn's disease $(\times 80)$.

Statistical analysis was performed according to Student's (two sample) $t$ test.

The numbers of IgD and IgE containing cells in controls and inflammatory bowel disease were too low to perform reliable statistical analysis and are therefore not further mentioned in the results.

\section{Results}

Rectal mucosa biopsy specimens of three groups of patients (controls, ulcerative colitis, and Crohn's disease) showed the same results as the sigmoid colonic biopsy specimens. The lamina propria area 
Table 1 Lamina propria area per millimetre mucosa length

\begin{tabular}{llll}
\hline Group & No. & Mean $\left(\mathrm{mm}^{2}\right)$ & $\pm S D\left(\mathrm{~mm}^{2}\right)$ \\
\hline Controls & 10 & $0 \cdot 1144$ & \pm 0.0155 \\
a Ulcerative colitis & 10 & 0.2006 & \pm 0.0505 \\
b Crohn's disease & 10 & $0 \cdot 1793$ & \pm 0.0398 \\
a +b Inflammatory bowel disease & 20 & 0.1900 & \pm 0.0455 \\
\hline
\end{tabular}

Eight sections were examined in each patient.

The lamina propria area per millimetre mucosa length in inflammatory bowel disease is significantly increased compared with controls $(\mathrm{P}<0.001)$.

Table 2 Number of Ig A, IgG and IgM containing cells per millimetre mucosa length $( \pm S D)$ in biopsy specimens

\begin{tabular}{|c|c|c|c|c|}
\hline Group & No. & $\operatorname{Ig} A$ & $\operatorname{Ig} G$ & $I g M$ \\
\hline $\begin{array}{l}\text { Rectum } \\
\text { Controls } \\
\text { Ulcerative colitis } \\
\text { Crohn's disease }\end{array}$ & $\begin{array}{l}10 \\
10 \\
10\end{array}$ & $\begin{array}{r}88( \pm 11) \\
173( \pm 72) \\
154( \pm 41)\end{array}$ & $\begin{array}{c}14( \pm 5) \\
118( \pm 68) \\
46( \pm 37)\end{array}$ & $\begin{array}{c}8( \pm 4) \\
15( \pm 8) \\
73( \pm 39)\end{array}$ \\
\hline $\begin{array}{l}\text { Sigmoid } \\
\text { Controls } \\
\text { Ulcerative colitis } \\
\text { Crohn's disease }\end{array}$ & $\begin{array}{l}10 \\
10 \\
10\end{array}$ & $\begin{array}{c}81( \pm 8) \\
164( \pm 53) \\
161( \pm 49)\end{array}$ & $\begin{array}{l}12( \pm 3) \\
97( \pm 58) \\
36( \pm 19)\end{array}$ & $\begin{array}{c}7( \pm 2) \\
15( \pm 6) \\
68( \pm 32)\end{array}$ \\
\hline $\begin{array}{l}\text { Transverse or descend } \\
\text { Active Crohn's diseas }\end{array}$ & ding ce & $181( \pm 50)$ & $105( \pm 13)$ & $59( \pm 16)$ \\
\hline
\end{tabular}

per mm mucosal length was significantly smaller in controls than in inflammatory bowel disease. The difference between the lamina propria area in ulcerative colitis and Crohn's disease was not significant $(P>0.05)$ (Table 1).

In controls IgA containing cells were predominant and those containing IgG and IgM were in a small minority (Table 2, Fig. 2a, b).

In ulcerative colitis the IgG containing cells formed an important proportion of the lamina propria cellular infiltrate but the $\operatorname{IgA}$ containing cells remained the major cell class. A high activity of inflammation appeared to be correlated with large numbers of IgG containing cells. The number of IgM containing cells was almost the same as in the control group (Table 2, Fig. 2c, d). Most IgG containing cells were localised in the basal layers of the lamina propria.

In the 10 patients with Crohn's disease the most important immunoglobulin containing cell class was IgA. The number of the IgM containing cells per $\mathrm{mm}$ mucosal length was significantly increased compared with the control group and the patients with ulcerative colitis. The number of IgG cells varied with the degree of colonic inflammation (Fig. 2e, f). In seven of the 10 patients with Crohn's disease we found in active inflamed mucosa of the transverse or descending part of the colon the same high number of IgG containing cells as in active

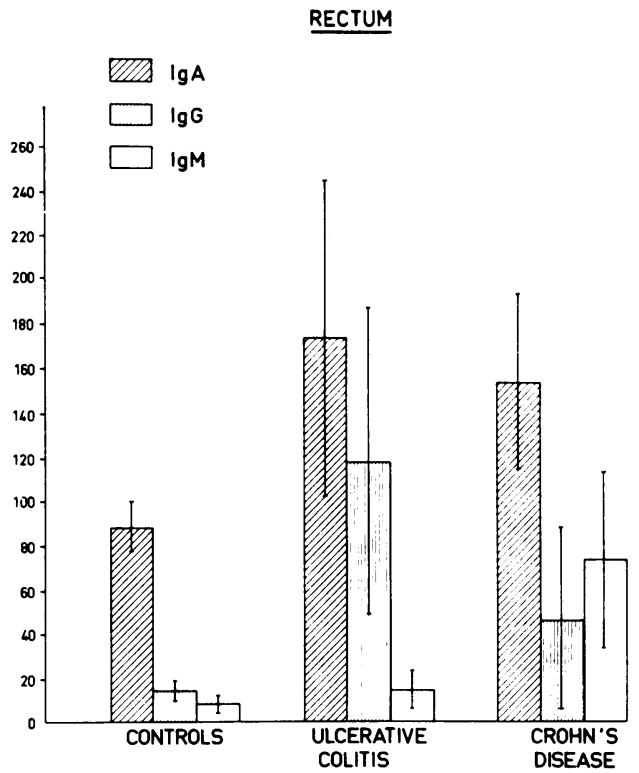

IMMUNOGLOBULIN CONTAINING CELLS PER MM MUCOSA LENGTH.

Fig. 3 Number of immunoglobulin containing cells per millimetre rectal mucosa in 10 controls, 10 patients with ulcerative colitis, and 10 patients with Crohn's disease $(\mathbf{E}= \pm I S D)$.

Table 3 Number of $\operatorname{Ig} A, \operatorname{Ig} G$, and IgM containing cells per square millimetre lamina propria area $( \pm S D)$ in biopsy specimens

\begin{tabular}{lcllc}
\hline Group & No. & IgA & $I g G$ & $I g M$ \\
\hline Rectum & & & & \\
Controls & 10 & $806( \pm 159)$ & $121( \pm 31)$ & $70( \pm 25)$ \\
Ulcerative colitis & 10 & $932( \pm 436)$ & $567( \pm 257)$ & $77( \pm 36)$ \\
Crohn's disease & 10 & $979( \pm 222)$ & $271( \pm 239)$ & $422( \pm 184)$ \\
Sigmoid & & & & \\
Controls & 10 & $790( \pm 156)$ & $118( \pm 45)$ & $63( \pm 30)$ \\
Ulcerative colitis & 10 & $832( \pm 317)$ & $504( \pm 226)$ & $85( \pm 39)$ \\
Crohn's disease & 10 & $985( \pm 185)$ & $203( \pm 105)$ & $350( \pm 118)$ \\
& & & &
\end{tabular}

ulcerative colitis (Table 2, Fig. $2 \mathrm{~g}$, h). The number of IgM containing cells per $\mathrm{mm}$ mucosal length was independent of the degree of activity of the inflammation. The immunoglobulin containing cell numbers per $\mathrm{mm}$ of rectal mucosa in the three groups of patients are shown in Fig. 3.

To investigate whether in inflammatory bowel disease the increase of numbers of immunoglobulin containing cells per $\mathrm{mm}$ mucosal length was not only due to an increase of the lamina propria area per $\mathrm{mm}$ mucosal length we counted the immunoglobulin containing cells also per square $\mathrm{mm}$ lamina propria area. The results, presented in Table 3, show that the increase of IgA containing cells per $\mathrm{mm}$ mucosal length is mainly due to an increase of 
the lamina propria area. However, the changes in numbers of IgG and IgM containing cells in inflammatory bowel disease are also caused by an increase of the density of these cells as expressed as number of immunoglobulin containing cells per square mm lamina propria area.

\section{Discussion}

This study shows that in inflammatory bowel disease a marked increase in lamina propria area per $\mathrm{mm}$ mucosal length is found. The increase of the number of immunoglobulin containing cells in ulcerative colitis and Crohn's disease is caused by different classes of immunoglobulin containing cells.

Two mechanisms are responsible for the enlargement of the lamina propria area per mm mucosal length in inflammatory bowel disease compared with controls: (1) the mucosal thickness increases because of hyperaemia, oedema, and the inflammatory infiltrate, (2) there is a loss of crypts.

We have expressed the number of immunoglobulin containing cells in two different ways-that is, per $\mathrm{mm}$ mucosal length and per square $\mathrm{mm}$ lamina propria area. As shown in Fig 3 the number of immunoglobulin containing cells per mm mucosal length was markedly increased in inflammatory bowel disease. The increase of the IgA containing cell-number per $\mathrm{mm}$ mucosal length in inflammatory bowel disease is mainly due to the increase of the lamina propria area per mm mucosal length. The increased numbers of IgG and IgM containing cells are also due to an increased density of the cellular infiltrate as measured per square $\mathrm{mm}$ lamina propria area.

In quantitative studies on immunoglobulin containing cells in the bowel mucosa using immunofluorescence techniques most authors have expressed their results in terms of numbers per square $\mathrm{mm}$ of lamina propria area. This is unsatisfactory, as it does not take account of the increase in the total numbers of immunoglobulin containing cells that can occur in the lamina propria. The numbers of cells per unit area may be the same in two groups of subjects, yet, if the thickness of the lamina propria is greater in one than the other, the total numbers of cells may be very different in the two groups. Therefore we used as an index the immunoglobulin containing cell-number per $\mathrm{mm}$ mucosal length. In paraplast embedded sections this is simple and convenient to determine.

Most previous studies about immunoglobulin containing cells in inflammatory bowel disease have been performed with an immunofluorescence technique. Because of the impermanence of the frozen sections and the limited possibilities for screening of these sections quantitative studies are relatively difficult to carry out and to reproduce. This is possibly one of the causes of discrepancies between reports about numbers of immunoglobulin containing cells in the lamina propria of the gastrointestinal tract.

Our results concerning the number of $\operatorname{IgA}$ containing cells in the colonic lamina propria are similar to most immunofluorescence studies. ${ }^{3-5}$ Some authors found a decreased number of IgA containing cells compared with normal ${ }^{2} 78$ but this difference may be explained by the use of a semi-quantitative counting technique. In the present study we found a relative decrease in the IgA containing cell population in inflammatory bowel disease because of the relatively large increase in the IgG containing cells in ulcerative colitis and of the IgG and IgM containing cells in Crohn's disease.

The rise in the IgG containing cell number per $\mathrm{mm}$ mucosa length in inflammatory bowel disease appears to be dependent on the degree of inflammation and does not significantly differ in ulcerative colitis and in active inflammation in Crohn's disease (Table 2). In chronic quiescent Crohn's disease the number of IgG containing cells is low and tends to be comparable with the controls (Table 2).

In addition, we have studied the number of IgG containing cells per $\mathrm{mm}$ mucosal length in six colectomy specimens from patients with active Crohn's disease. The mean number of IgG containing cells per mm mucosal length in these colectomy specimens was also high (166 \pm 44$)$, which is in agreement with our biopsy findings.

The IgM containing cell number in Crohn's disease is a controversial subject. Green and Fox ${ }^{18}$ found in affected areas of Crohn's disease an increase of IgM containing cells and Meuwissen et al. ${ }^{7}$ found a significant reduction of the $\operatorname{IgA} / \operatorname{IgM}$ plasma cell ratio compared with ulcerative colitis and controls. In our study, using immunoperoxidase staining in paraplast sections, the IgM containing cell number per $\mathrm{mm}$ mucosal length in Crohn's disease, quiescent or active, is increased compared with the control group and with ulcerative colitis patients. In relatively quiescent parts of the colon in Crohn's disease the number of IgM containing cells is increased and this is of diagnostic importance in distinguishing this condition from ulcerative colitis.

It is concluded that immunoperoxidase staining for immunoglobulin containing cells on colonic mucosal biopsy specimens will differentiate the pathology of Crohn's disease from ulcerative colitis.

We are very grateful to Dr J Hermans of the Division of Medical Statistics, University Medical Centre, 
Leiden, for carrying out the statistical analysis of the data.

\section{References}

${ }^{1}$ Crabbé PA, Heremans JF. The distribution of immunoglobulin-containing cells along the human gastrointestinal tract. Gastroenterology 1966; 51 : 305-16.

${ }^{2}$ Gelzayd EA, Kraft SC, Fitch FW, Kirsner, JB. Distribution of immunoglobulins in human rectal mucosa. II Ulcerative colitis and abnormal mucosal control subjects. Gastroenterology 1968; 54: 341-7.

${ }^{3}$ Söltoft J, Binder V, Gudmand-Höyer E. Intestinal immunoglobulin in ulcerative colitis. Scand $J$ Gastroenterol 1973; 8: 293-300.

${ }^{4}$ Skinner JM, Whitehead R. The plasma cells in inflammatory bowel disease of the colon: a quantitative study. J Clin Pathol 1974; 27 : 643-6.

${ }^{5}$ Baklien K, Brandtzaeg P. Comparative mapping of the local distribution of immunoglobulin-containing cells in ulcerative colitis and Crohn's disease of the colon. Clin Exp Immunol 1975; 22: 197-209.

${ }^{6}$ Baklien $\mathbf{K}$, Brandtzaeg $\mathbf{P}$. Immunohistochemical characterization of local immunoglobulin formation in Crohn's disease of the ileum. Scand J Gastroenterol 1976; 11 : 447-57.

${ }^{7}$ Meuwissen SGM, Feltkamp-Vroom ThM, Brutel de la Rivière $A$, von dem Borne AEGKr, Tytgat GN, Analysis of the lympho-plasmacytic infiltrate in Crohn's disease with special reference to identification of lymphocyte-subpopulations. Gut 1976; 17: 770-80.

${ }^{8} \mathrm{O}$ 'Donoghue DP, Kumar P. Rectal IgE cells in inflammatory bowel disease. Gut 1979; 20 : 149-53.
${ }^{9}$ Otto HF, Gebbers JO. Immunhistologische Untersuchungen zur lokalen humoralen Immunreaktion bei unbehandelter Colitis ulcerosa. Inn Med 1978; 2: 69-77.

${ }^{10}$ Morson BC. In Summers, SC, ed. Pathology annual. New York: Appleton-Century-Crofts, 1974: 209-30.

${ }^{11}$ Whitehead R. Mucosal biopsy of the gastro-intestinal tract. London: WB Saunders, 1973: 139-66.

${ }^{12}$ Meijer, CJLM, Bosman FT, Lindeman J. Evidence for predominant involvement of the B-cell system in the inflammatory process in Crohn's disease. Scand $J$ Gastroenterol 1979; 14: 21-32.

${ }^{13}$ Bosman FT, Lindeman J, Kuiper G, van der Wal A, Kreuning $J$. The influence of fixation on immunoperoxidase staining of plasma cells in paraffin sections of intestinal biopsy specimens. Histochemistry 1977; 53: 57-62.

${ }^{14}$ Sternberger L. Immunocytochemistry. Englewood Cliffs, NJ : Prentice Hall, 1974: 53.

${ }^{15}$ Hijmans W, Schuit HRE, Klein F. An immunofluorescence procedure for detection of intracellular immunoglobulins. Immunology 1969; 4: 457-72.

${ }^{16}$ Rosekrans PCM, Meijer CJLM, Cornelisse CJ, van der Wal AM, Lindeman J. Use of morphometry and immunohistochemistry of small intestinal biopsy specimens in the diagnosis of food allergy. J Clin Pathol 1980; 33: $125-30$.

${ }^{17}$ Brandtzaeg P, Baklien K, Fausa O, Hoel PS. Immunohistochemical characterization of local immunoglobulin formation in ulcerative colitis. Gastroenterology 1974; 66: 1123-36.

${ }^{18}$ Green FHY, Fox H. The distribution of mucosal antibodies in the bowel of patients with Crohn's disease. Gut 1975; 16: 125-31. 